\title{
Unmasking by neuraminidase of specific chorionic gonadotrophin binding activity of human placental syncytiotrophoblast
}

\author{
S. Paul* and B. L. Jailkhani† \\ *Department of Biochemistry and ${ }^{+}$Neurosciences Center, All-India Institute of Medical \\ Sciences, New Delhi, India
}

\begin{abstract}
Summary. Purified human placental syncytiotrophoblast consistently failed to bind specifically to ${ }^{125} \mathrm{I}$-labelled hCG. Treatment of the syncytiotrophoblast with neuraminidase resulted in the ability to bind ${ }^{125}$ I-labelled hCG that was displaceable by excess of unlabelled hCG. Neuraminidase treatment removed $73.8 \%$ of the total neuraminic acid of syncytiotrophoblast. The specific binding of ${ }^{125} \mathrm{I}$-labelled hCG increased linearly with increasing amount of neuraminidase-treated syncytiotrophoblast, was saturable and had a $K_{\mathrm{a}}=1.6 \times 10^{7} \mathrm{M}^{-1}$. Excess of $\mathrm{GH}$, prolactin, placental lactogen or insulin did not inhibit the binding, whereas LH did so completely and FSH partly.
\end{abstract}

\section{Introduction}

The hormone human chorionic gonadotrophin (hCG) is reported to stimulate a number of metabolic activities in the human placenta, including steroid synthesis (Demers, Gabbe, Villee \& Greep, 1973; Menon \& Jaffe, 1973; Gnanaprakasam \& Talwar, 1975; Guichard, de Ikonicoff \& Cedard, 1975). If this represents a direct effect of hCG on the syncytiotrophoblast, the steroid-producing tissue in the placenta (Baillie, Cameron, Grifiths \& Hart, 1965), it should be mediated by association of hCG to specific receptor binding sites on the syncytiotrophoblast, as in other hormone-target tissue interactions. HCG is synthesized by the syncytiotrophoblast, and is detectable on the surface of this tissue (Paul, Jailkhani \& Talwar, 1978). Whether part or all of the hCG present on the syncytiotrophoblast surface is receptor bound is not known. We have therefore investigated the expression of receptors for hCG on human syncytiotrophoblast.

\section{Materials and Methods}

Full-term human placentae from normal pregnancies were collected in tissue culture Medium 199 (Gibco, Paisley, Scotland) from the Department of Gynaecology \& Obstetrics, AIIMS, New Delhi, or the Frauenklinik of the University of Kiel. The central chorionic villus-rich tissue was obtained by dissection and processed for isolation of syncytiotrophoblast as described in detail elsewhere (Paul et al., 1978). Purified syncytiotrophoblast was maintained in tissue culture in a viable and metabolically active state (Paul et al., 1978; Paul, Jailkhani, Gupta \& Talwar, 1979). The preparations used for the hCG binding experiments had been maintained in culture for 2-11 days. The DNA content of syncytiotrophoblast was estimated according to Burton (1956) using calf thymus DNA (Sigma, Type I) as standard. For the neuraminidase treatment,

\footnotetext{
* Present address: University Frauenklinik, Hegewischstrasse 4, 2300 Kiel 1, West Germany.
} 
syncytiotrophoblast with a DNA content of 300-350 $\mu \mathrm{g}$ was washed twice with $10 \mathrm{ml}$ Medium 199, resuspended in $3 \mathrm{ml}$ Medium 199, pH 6.0, containing 0.3 units neuraminidase (Sigma, Type VI) $/ \mathrm{ml}$ and $0.03 \%$ bovine serum albumin (BSA), incubated for $2 \mathrm{~h}$ at $37^{\circ} \mathrm{C}$, and finally washed exhaustively with Medium 199 to remove neuraminidase. The sialic acid content of untreated and neuraminidase-treated syncytiotrophoblast was measured according to Jourdin, Dean \& Roseman (1971), following its release from the cells by treatment with $0.1 \mathrm{~N}$-sulphuric acid (Warren, 1959). The crude particulate fractions of syncytiotrophoblast were obtained by homogenization of the tissue in 10 volumes of $50 \mathrm{~mm}$-Tris- $\mathrm{HCl}$ buffer, $\mathrm{pH} 7 \cdot 2$, with a Brinkman Polytron, centrifugation of the homogenate at $600 \mathrm{~g}$ for $30 \mathrm{~min}$ at $4{ }^{\circ} \mathrm{C}$, and resuspension of the

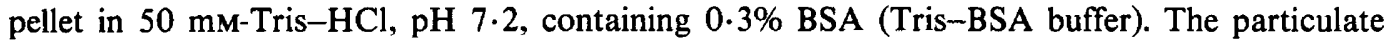
fractions were stored at $-20^{\circ} \mathrm{C}$ until used. Purified hCG $\left(10^{4} \mathrm{i} . \mathrm{u} . / \mathrm{mg}\right)$ was iodinated with $\mathrm{Na}^{125} \mathrm{I}$ (Radiochemical Centre, Amersham, U.K.) according to Saxena, Hasan, Haour \& SchmidtGollwitzer (1974). The specific activity of ${ }^{125} \mathrm{I}$-labelled hCG was $40-50 \mu \mathrm{Ci} / \mu \mathrm{g}$ as determined by radioimmunoassay. The particulate fraction was incubated with ${ }^{125} \mathrm{I}$-labelled hCG $\left(10^{5} \mathrm{c} . \mathrm{p} . \mathrm{m}\right.$. $)$ in a total volume of $0.5 \mathrm{ml}$ Tris-BSA buffer for $2 \mathrm{~h}$ at $37^{\circ} \mathrm{C}$ or $24 \mathrm{~h}$ at $4^{\circ} \mathrm{C}$, in the absence and presence of $10 \mu \mathrm{g}$ non-radioactive hCG (Sigma, $3 \times 10^{3} \mathrm{i} . \mathrm{u} . / \mathrm{mg}$ ). At the end of the incubation, the assay tubes were centrifuged at $1000 \mathrm{~g}$ for $15 \mathrm{~min}$, the pellets washed once with $2 \mathrm{ml}$ Tris-BSA buffer, and counted in a gamma spectrometer. The specific binding was calculated as c.p.m. bound in the absence of non-radioactive hCG minus c.p.m. bound in the presence of 10 $\mu \mathrm{g}$ non-radioactive hCG. Ovine LH (S-19), ovine FSH (S-11), ovine GH (S-8) and ovine prolactin (S-12) were gifts from NIAMDD, NIH, Bethesda, U.S.A. Insulin was purchased from Boots, India, and human placental lactogen from Nutritional Biochemicals Company, Cleveland, Ohio, U.S.A.

\section{Results}

The syncytiotrophoblastic particulate fractions exhibited a low level of binding to ${ }^{125}$ I-labelled hCG that was not significantly different in the absence and presence of excess $(10 \mu \mathrm{g})$ of non-radioactive hCG (Table 1), indicating that the syncytiotrophoblastic particulate fractions did not bind hCG specifically. When the particulate fractions were pretreated with neuraminidase in Medium 199, $\mathrm{pH} 6$, there was a 9-fold increase in the binding of ${ }^{125}$ I-labelled hCG (Table 1): $78.1 \%$ of the binding was displaceable by excess non-radioactive hCG, this value thus representing the specific ${ }^{125} \mathrm{I}$-labelled $\mathrm{hCG}$ binding component. The binding after pretreatment at $\mathrm{pH} 6$ without neuraminidase was indistinguishable from that with untreated

Table 1. Unmasking of ${ }^{12} 5$ I-labelled hCG binding activity of syncytiotrophoblast by neuraminidase

\begin{tabular}{|c|c|c|c|}
\hline \multirow[b]{2}{*}{ Treatment } & \multirow[b]{2}{*}{$\mathbf{N}$} & \multicolumn{2}{|c|}{ 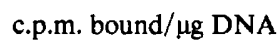 } \\
\hline & & Total & Non-specific \\
\hline $\begin{array}{l}\text { None } \\
\text { Neuraminidase, pH } 6 \\
\text { Medium 199, pH } 6\end{array}$ & $\begin{array}{l}8 \\
8 \\
3\end{array}$ & $\begin{array}{c}68 \\
556^{*} \\
58\end{array}$ & $\begin{array}{r}57 \\
122 \\
80\end{array}$ \\
\hline
\end{tabular}

Details of the treatments that syncytiotrophoblast received are given in the text. The particulate fractions of the treated syncytiotrophoblast preparations (7.9-15.0 $\mu \mathrm{g}$ DNA) were used for the ${ }^{125}$ I-labelled hCG binding assays. Non-specific binding was determined in the presence of $10 \mu \mathrm{g}$ non-radioactive hCG. $\mathrm{N}$ is the number of different syncytiotrophoblast preparations treated, each in triplicate.

* $P<0.001$ compared to non-specific binding. 
particulate fractions (Table 1). Colorimetric determination of sialic acid yielded values of 0.42 $\mu \mathrm{g}$ sialic acid/ $\mu \mathrm{g}$ DNA for untreated syncytiotrophoblast, and $0.11 \mu \mathrm{g}$ sialic acid/ $\mu \mathrm{g}$ DNA for neuraminidase-treated syncytiotrophoblast, treatment with neuraminidase liberating $73.8 \pm$ $9.4 \%$ of the syncytiotrophoblast-associated sialic acid.

Incubation with progressively increasing quantities of ${ }^{125} \mathrm{I}$-labelled $\mathrm{hCG}$ revealed the saturability of the syncytiotrophoblast binding sites (Text-fig. 1a). A linear increase of specific ${ }^{125}$ I-labelled hCG binding was obtained with increasing amount of the neuraminidase-treated syncytiotrophoblast (Text-fig. 1b). Non-radioactive human placental lactogen, prolactin, GH and insulin failed to compete with ${ }^{125}$ I-labelled hCG for binding to the syncytiotrophoblast binding sites, whereas $\mathrm{LH}$ and FSH, hormones possessing considerable amino acid homology with hCG (Ross, 1977), inhibited the binding completely and partly respectively (Table 2).
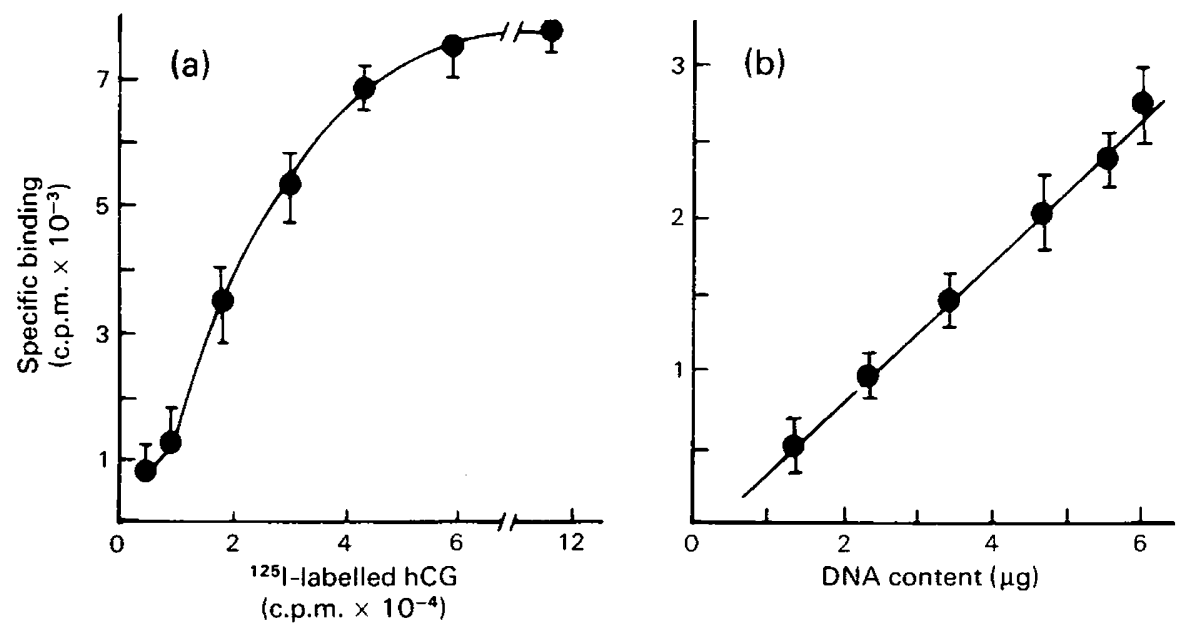

Text-fig. 1. (a) Saturation of specific ${ }^{125}$ I-labelled hCG binding to neuraminidase-treated syncytiotrophoblast, and (b) specific ${ }^{125}$ I-labelled hCG binding to increasing amount of neuraminidase-treated syncytiotrophoblastic particulate fraction. Values are mean \pm s.d. for 3 replicates.

Table 2. Ligand specificity of binding of ${ }^{125}$ I-labelled hCG to neuraminidase-treated syncytiotrophoblast

\begin{tabular}{|c|c|}
\hline Hormone & $\begin{array}{l}\% \text { inhibition of } \\
\text { specific binding }\end{array}$ \\
\hline hCG & 100 (3590 c.p.m.) \\
\hline LH & 96 \\
\hline FSH & 47 \\
\hline Human placental lactogen & 1 \\
\hline Prolactin & 5 \\
\hline GH & 0 \\
\hline Insulin & 3 \\
\hline
\end{tabular}

The particulate fraction of neuraminidasetreated syncytiotrophoblast (DNA content: $8.5 \mu \mathrm{g})$ was incubated with ${ }^{125}$ I-labelled hCG in the absence and presence of $10 \mu \mathrm{g}$ each of the indicated hormones for $24 \mathrm{~h}$ at $4^{\circ} \mathrm{C}$. Values for inhibition of ${ }^{125}$ I-labelled hCG binding were computed relative to the inhibition obtained with $10 \mu \mathrm{g} \mathrm{hCG}(100 \%)$. Values are means of triplicate determinations. 
Scatchard plots of binding of hCG to two preparations of neuraminidase-treated syncytiotrophoblastic particulate fractions revealed linear curves (Text-fig. 2). The mean affinity constant $\left(K_{\mathrm{a}}\right)$ was $1.6 \times 10^{7} \mathrm{M}^{-1}$, and the hCG binding capacity was $1.5 \times 10^{-7} \mathrm{~mol} / \mu \mathrm{g}$ DNA of the syncytiotrophoblast.

Neuraminidase activity in the neuraminidase-treated syncytiotrophoblast was undetectable by colorimetric sialic acid estimations using $N$-acetylneuramin-lactose as substrate, as well as by histochemical means. Therefore, the ability of the neuraminidase-treated syncytiotrophoblast to bind hCG specifically was not due to desialylation of the hormone by the cells, analogous to increased binding of desialylated hCG, compared to native hCG, to gonadal receptors (Catt \& Dufau, 1975).

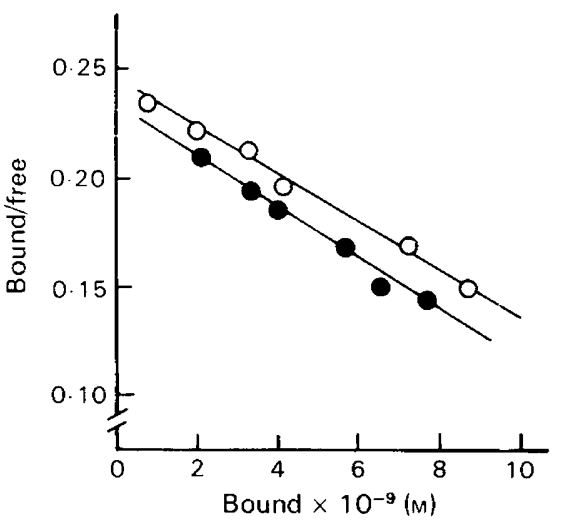

Text-fig. 2. Scatchard plots of ${ }^{125}$ I-labelled hCG binding to particulate fractions of neuraminidase-treated syncytiotrophoblast from 2 placentae $(0-0,0)$, in the presence of various quantities of unlabelled hCG (10-500 ng; $\left.10^{4} \mathrm{i} . \mathrm{u} . / \mathrm{mg}\right)$. The molecular weight of hCG used for computation was 47000 (Bahl, 1969).

\section{Discussion}

The method used in this study for isolation of the syncytiotrophoblast yields preparations composed of large syncytial portions, free of contamination with other cell types, as judged microscopically; the only contaminants are acellular connective tissue fragments (about 5\%) (Paul et al 1978, 1979). Expression of the trophoblastic markers hCG, placental lactogen, oxytocinase and pregnancy-specific $\beta_{1}$-glycoprotein was demonstrated by a sandwich immunofluorescence test (Paul et al., 1978). Syncytiotrophoblast isolated from full-term placentae and maintained in culture retained the capacity to synthesize hCG and progesterone, and the output of hCG did not diminish during the period of culture (Paul et al., 1978; Paul, Das, Jailkhani \& Talwar, 1981). Based on these observations, we conclude that the syncytiotrophoblast preparations investigated in this study for expression of hCG receptors are adequately representative of placental syncytiotrophoblast in vivo.

Untreated syncytiotrophoblast may have failed to bind hCG specifically because its hCG receptors were already saturated by endogenous hCG, and neuraminidase, by stripping away receptor-bound hCG, could have unmasked the receptors. However, immunohistochemical localization studies failed to reveal any difference in the intensity of reaction for hCG on untreated and neuraminidase-treated syncytiotrophoblast, and there was no detectable release of hCG during treatment with neuraminidase (Paul, 1979). It is therefore more likely that the neuraminidase-mediated removal of sialic acid from the syncytiotrophoblast surface exposes previously masked receptors for hCG, as postulated in relation to histocompatibility antigens (Currie, van Doorninck \& Bagshawe, 1965). The significantly lower affinity of the 
syncytiotrophoblast receptors for hCG, compared to testicular and ovarian receptors (Catt \& Dufau, 1975; Paul, 1979), may be due to the incomplete unmasking action of neuraminidase, and persistence of steric constraints for the association of hCG to the receptors.

The absence of any overt hCG binding activity of untreated syncytiotrophoblast argues against a direct effect of hCG on the metabolism of this tissue, and is in concordance with the failure of hCG to stimulate conversion of cholesterol/pregnenolone to progesterone by purified syncytiotrophoblast in vitro (Paul et al., 1981). The stimulatory effect of hCG on steroidogenesis, noted in studies with unfractionated placental tissue (Villee \& Gabbe, 1972; Guichard et al., 1975), may represent a secondary effect of the hormone on syncytiotrophoblastic metabolism; the placenta consists of a number of cell types, and hCG may act on a cell type such as cytotrophoblasts, or cells of the villous matrix, to increase production of cofactors/steroidal precursors that are essential for synthesis of oestrogens and progesterone by syncytiotrophoblast. The physiological significance of the neuraminidase-exposed hCG receptors on syncytiotrophoblast is not immediately obvious. However, the existence of these masked hCG receptors does indicate that the syncytiotrophoblast is potentially capable of expressing hCG receptors in overt form. For example, it is possible that the hCG receptors are overtly expressed at early developmental stages, analogous to their reported presence on mouse blastocyst (Sengupta, Gupta, Manchanda \& Talwar, 1978), and later are sterically masked by surface glycoproteins.

This study was supported by the Family Planning Foundation, India, and the Alexander von Humboldt Foundation, Federal Republic of Germany. We thank Professor G. P. Talwar for making available purified hCG and for discussion, and Professor L. Mettler and Mr A. Czuppon for help with neuraminic acid determinations.

\section{References}

Bahl, O.P. (1969) Human chorionic gonadotropin: purification and physiochemical properties. $J$. biol. Chem. 244, 567-574.

Baillie, A.H., Cameron, E.H.D., Grifiths, K. \& Hart, D.McK. (1965) 3- $\beta$-Hydroxysteroid dehydrogenase in the adrenal gland and placenta. J. Endocr. 31, 227-233.

Burton, K. (1956) A study of the conditions and mechanism of the diphenylamine reaction for the colorimetric estimation of deoxyribonucleic acid. Biochem. J. 62, 315-323.

Catt, K.J. \& Dufau, M.L. (1975) Gonadal receptors for luteinizing hormone and chorionic gonadotropin. In Methods in Enzymology, Vol. 37, pp. 167-193. Eds B. W. O'Malley \& J. G. Hardman. Academic Press, New York.

Currie, G.A., van Doorninck, W. \& Bagshawe, K.D. (1965) The effect of neuraminidase on the immunogenicity of early mouse trophoblast. Nature, Lond. 219, 191-192.

Demers, L.M., Gabbe, S.G., Villee, C.A. \& Greep, R.O. (1973) Human chorionic gonadotropin mediated glycogenolysis in human placental villi: a role of prostaglandins. Biochim. Biophys. Acta 313, 202210 .

Gnanaprakasam, M.G. \& Talwar, G.P. (1975) Influence of hCG on placental metabolism. In Regulation of Growth and Differentiated Function in Eukaryote Cells, pp. 529-532. Ed. G. P. Talwar. Raven Press, New York.
Guichard, A., de Ikonicoff, L.K. \& Cedard, L. (1975) Activite de la delta 5-3 beta hydroxy steroide dehydrogenase dans le placenta human a terme apres culture: influence de l'hormone gonadotrope chorionique. C. r. hebd. Séanc. Acad. Sci. Paris D 280, 1481-1484.

Jourdin, G.W., Dean, L. \& Roseman, S.J. (1971) A periodate-resorcinol method for the quantitative estimation of free sialic acids and their glycosides. $J$. biol. Chem. 246, 430-435.

Menon, K.M.J. \& Jaffe, R.B. (1973) Chorionic gonadotropin sensitive adenylate cyclase in the human term placenta. J. clin. Endocr. Metab. 36, 1104-1109.

Paul, S. (1979) Isolation, characteristics and immunobiology of human placental syncytiotrophoblast. Ph.D. thesis, All India Institute of Medical Sciences, New Delhi.

Paul, S., Jailkhani, B.L. \& Talwar, G.P. (1978) Isolation and functional maintenance in culture of human syncytiotrophoblasts. Ind. J. exp. Biol. 16, 12261232.

Paul, S., Jailkhani, B.L., Gupta, P.D. \& Talwar, G.P. (1979) Isolation, functional maintenance and properties of human placental syncytiotrophoblasts. In Recent Advances in Reproduction and Regulation of Fertility, pp. 375-385. Ed. G. P. Talwar. ElsevierNorth Holland, Amsterdam.

Paul, S., Das, C., Jailkhani, B.L. \& Talwar, G.P. (1981) Progesterone synthesis by human placental syncytiotrophoblast in vitro-preferred precursor and 
effect of human chorionic gonadotropin. J. Steroid Biochem. 14, 311-313.

Ross, G.T. (1977) Clinical relevance of research on the structure of human chorionic gonadotropin. Am. J. Obstet. Gynec. 129, 795-808.

Saxena, R.B., Hasan, S.H., Haour, F. \& SchmidtGollwitzer, M. (1974) Radioreceptor assay of human chorionic gonadotropin: detection of early pregnancy. Science, N.Y. 184, 793-795.

Sengupta, J., Gupta, P.D., Manchanda, S.K. \& Talwar,
G.P. (1978) Immunocytochemical localization of binding sites for luteinizing hormone and human chorionic gonadotrophin in preimplantation mouse embryos. J. Reprod. Fert. 52, 163-165.

Villee, C.A. \& Gabbe, S.G. (1972) Effects of gonadotropins on placental function. In Gonadotropins, pp. 309-317. Eds B. B. Saxena, C. G. Beling \& H. M. Gandy. Wiley Interscience, New York.

Warren, L. (1959) The thiobarbituric acid assay of sialic acids. J. biol. Chem. 234, 1971-1975.

Received 15 December 1981 